\title{
Komposisi Kimia Deposisi Basah di Jakarta, Serpong, Bandung, Kototabang, dan Maros Selama Tahun 2015-2019
}

\section{Chemical Composition of Wet Deposition in Jakarta, Serpong, Bandung, Kototabang, and Maros During 2015-2019}

\author{
Retno Puji Lestari ${ }^{1}$, Muharam Syam Nugraha ${ }^{2}$, Asri Indrawati ${ }^{3}$, Suryanti ${ }^{2}$, Eka \\ Suharguniyawan ${ }^{2}$, Sri Wulan Siti Khotijah ${ }^{2}$, Yuni Kartika² ${ }^{2}$, Ahmad Rafly Juliana ${ }^{2}$, Bambang \\ Hindratmo ${ }^{1}$, Dyah Aries Tanti ${ }^{3}$, dan Ricky Nelson ${ }^{1}$ \\ 'Pusat Standardisasi Instrumen Kualitas Lingkungan Hidup (PSIKLH)-KLHK, \\ Kawasan PUSPIPTEK Gedung 210, Serpong - Tangerang Selatan 15310. \\ ${ }_{2}^{2}$ Pusat Informasi Perubahan Iklim, Badan Meteorologi, Klimatologi, dan Geofisika (BMKG). \\ Jl. Angkasa I No.2 Kemayoran Jakarta Pusat, DKI Jakarta 10720. \\ ${ }^{3}$ Lembaga Penerbangan dan Antariksa Nasional (LAPAN)- Badan Riset dan Inovasi Nasional (BRIN), \\ Jl. Dr.Djundjunan No 133 Bandung 40173. \\ E-mail: emc_acdep@yahoo.com
}

Diterima 4 Oktober 2021, direvisi 7 Oktober 2021, disetujui 13 Oktober 2021

\begin{abstract}
ABSTRAK
Komposisi Kimia Deposisi Basah di Jakarta, Serpong, Bandung, Kototabang, dan Maros Selama Tahun 2015-2019. Dalam dekade terakhir, peningkatan konsumsi bahan bakar fosil yang berasal dari pembangunan ekonomi yang cepat dari sektor transportasi dan industri. Kegiatan tersebut telah menghasilkan emisi berbagai polutan udara dan menyebabkan masalah lingkungan di seluruh dunia, tak terkecuali di Indonesia. Deposisi asam yang diakibatkan oleh pencemaran udara masih merupakan isu wilayah di Asia. Jaringan Pemantauan Deposisi Asam di Asia Timur (EANET) yang mencakup Asia Timur Laut dan Tenggara, telah melakukan kegiatan pemantauan deposisi asam dan pengaruhnya terhadap ekosistem. Terdapat 5 (lima) lokasi pemantauan deposisi asam di Indonesia yang tergabung dalam EANET, yaitu Jakarta, Serpong, Bandung, Kototabang, dan Maros. Parameter air hujan yang dianalisis adalah $\mathrm{pH}$, daya hantar listrik, $\mathrm{Na}^{+}, \mathrm{K}^{+}, \mathrm{Ca}^{2+}, \mathrm{Mg}^{2+}, \mathrm{NH}_{4}^{+}, \mathrm{Cl}^{-}, \mathrm{NO}_{3}^{-}$, dan $\mathrm{SO}_{4}^{2-}$ dan $\mathrm{pH}$ air hujan dapat mengindikasikan potensi terjadinya deposisi asam. Selama tahun 2015-2019, rata-rata tingkat keasaman air hujan di Jakarta, Serpong, Bandung, Kototabang, dan Maros masing-masing adalah 4,85, $5,17,5,55,5,23$, dan 5,28. Meskipun masih terindikasi mengalami efek deposisi asam, nilai $\mathrm{pH}$ tersebut relatif lebih tinggi dibandingkan dengan periode sebelumnya. Potensi penyebab keasaman air hujan

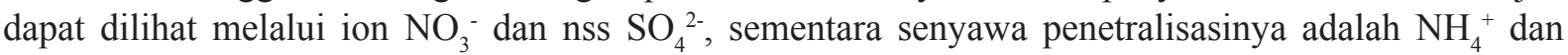
nss $\mathrm{Ca}^{2+}$. Fraksi ekuivalen nitrat menunjukkan bahwa $\mathrm{HNO}_{3}$ yang lebih berpengaruh dalam terjadinya deposisi asam di Jakarta, Serpong, dan Bandung, tetapi di Kototabang dan Maros lebih disebabkan oleh $\mathrm{H}_{2} \mathrm{SO}_{4}$. Fraksi ekuivalen amonium di Kototabang menunjukkan bahwa peran $\mathrm{CaCO}_{3}$ lebih dominan dalam menetralisasi senyawa asam, sementara di kota-kota lainnya lebih didominasi oleh $\mathrm{NH}_{3}$. Kajian ini mengindikasikan bahwa dominasi sumber pencemaran berasal dari kegiatan antropogenik.
\end{abstract}

Kata kunci: pencemaran udara, deposisi basah, $\mathrm{pH}$, keasaman, ion chromatography.

\section{ABSTRACT}

Chemical Composition of Wet Deposition in Jakarta, Serpong, Bandung, Kototabang, and Maros During 2015-2019. In recent decade, the growing consumption of fossil fuels has been driven by rapid economic development from transportation and industrial sectors. Those activities had led to enormous emissions of multiple air pollutants and related environmental problems throughout the world, including 
Indonesia. Acid deposition which was induced by air pollution remains as a regional issue in Asia. The Acid Deposition Monitoring Network in East Asia (EANET) covering the area of Northeast and Southeast Asia has been conducted the acid deposition monitoring and its effects on ecosystems. There are 5 (five) acid deposition monitoring sites in Indonesia which are included in EANET, namely Jakarta, Serpong, Bandung, Kototabang, and Maros. Rain water parameters analysed were $\mathrm{pH}$, conductivity, $\mathrm{Na}^{+}, \mathrm{K}^{+}$, $\mathrm{Ca}^{2+}, \mathrm{Mg}^{2+}, \mathrm{NH}_{4}^{+}, \mathrm{Cl}, \mathrm{NO}_{3}$, and $\mathrm{SO}_{4}^{2-}$. Rain water $\mathrm{pH}$ indicates the potential of acid deposition. During the year of 2015-2019, the average rain water acidity in Jakarta, Serpong, Bandung, Kotatabang, and Maros was 4.84, 5.17, 5.55, 5.23, and 5.28, respectively. Although indication of acid deposition still remained, those $\mathrm{pH}$ values are relatively higher than previous period. Potential causes for rain water acidity may be observed through $\mathrm{NO}_{3}^{-}$and nss $\mathrm{SO}_{4}^{2-}$, while the neutralizing species are $\mathrm{NH}_{4}^{+}$and nss $\mathrm{Ca}^{2+}$. The nitrate equivalent fraction indicates that $\mathrm{HNO}_{3}$ has a greater influence on the occurrence of acid deposition in Jakarta. Serpong, and Bandung, but in Kototabang and Maros it is likely caused by $\mathrm{H}_{2} \mathrm{SO}_{4}$. The ammonium equivalent fraction in Kototabang shows that the role of $\mathrm{CaCO}_{3}$ is more dominant in neutralization of acidic compounds, while in other cities it is more dominated by $\mathrm{NH}_{3}$. This study indicates that the dominant sources of pollution originate from anthropogenic activities.

Keywords: air pollution, wet deposition, $\mathrm{pH}$, acidity, ion chromatography.

\section{Pendahuluan}

Pencemaran udara dapat disebabkan oleh senyawa polutan yang dihasilkan dari kegiatan emisi sumber tidak bergerak seperti cerobong industri, pembangkit listrik, pembakaran sumber domestik, maupun insinerator (APIS, 2016; Burns et al., 2016; Cui et al., 2020; Duan et al., 2016). Pencemaran udara secara lebih lanjut dapat mengakibatkan terjadinya deposisi asam, yaitu salah satu fenomena yang menggambarkan turunnya senyawa bersifat asam dari atmosfer ke permukaan bumi (APIS, 2015). Asam yang mengandung sulfur dan nitrogen merupakan penyebab terjadinya pengasaman pada atmosfer (EANET, 2015b). Turunnya senyawa bersifat asam tersebut salah satunya melalui air hujan, yang dikenal dengan istilah deposisi basah. Polutan atmosfer dan deposisi telah terbukti dipengaruhi tidak hanya oleh sumber lokal tetapi juga oleh transportasi jarak jauh (Itahashi et al., 2020). Ion-ion $\mathrm{Na}^{+}, \mathrm{K}^{+}, \mathrm{Ca}^{2+}, \mathrm{Mg}^{2+}, \mathrm{NH}_{4}^{+}, \mathrm{Cl}^{-}, \mathrm{NO}_{3}^{-}$ , dan $\mathrm{SO}_{4}^{2-}$ yang terdapat pada deposisi asam merupakan komponen alami air hujan, namun konsentrasinya dapat dipengaruhi oleh berbagai kegiatan antropogenik sehingga dapat bersifat lebih asam.

Dalam perkembangannya sejak tahun 1998, melalui kegiatan pemantauan deposisi asam jaringan EANET yang dilakukan secara terpadu di 13 (tiga belas) negara di wilayah Asia Timur Laut dan Tenggara, terlihat bahwa tingkat deposisi sulfur dan nitrogen di negara-negara anggota jaringan memiliki konsentrasi lebih tinggi dibandingkan dengan negara Eropa dan Amerika (Sase, 2017). Berdasarkan hasil identifikasi sumber di Cina, diketahui bahwa deposisi asam memiliki hubungan yang erat antara terjadinya presipitasi dengan faktor sosio-ekonomi yang berhubungan dengan kegiatan antropogenik (Cui et al., 2020).

Kegiatan ini bertujuan untuk mengetahui konsentrasi pencemar parameter deposisi basah di beberapa wilayah di Indonesia yaitu Jakarta, Serpong, Bandung, Kototabang, dan Maros selama periode pemantauan tahun 2015-2019 dan melihat tren yang terjadi dibandingkan dengan periode sebelumnya. Badan Meteorologi Klimatologi dan Geofisika (BMKG) melakukan pemantauan di Jakarta, 
Kototabang, dan Maros, sedangkan Pusat Standardisasi Instrumentasi Kualitas Lingkungan Hidup $\quad-\quad$ Kementerian Lingkungan Hidup dan Kehutanan (PSIKLH-KLHK) melakukan pemantauan di Serpong, sementara Lembaga Penerbangan dan Antariksa Nasional - Badan Riset dan Inovasi Nasional (LAPAN-BRIN) melakukan kegiatan di Bandung.

\section{Metodologi}

Lokasi kegiatan sampling dilakukan di lima lokasi berbeda seperti terlihat pada Tabel 1. Sampel air hujan di Serpong dan Bandung dikumpulkan setiap hari hujan (event) menggunakan wet-only sampler, sementara di Jakarta, Kototabang, dan Maros dikumpulkan setiap minggu. Pengukuran $\mathrm{pH}$ dan daya hantar listrik di Kototabang dan Maros dilakukan secara on-site, kemudian sampel disimpan dalam botol polietilen dan diawetkan sebelum dikirimkan ke BMKG Jakarta. Sampel dari Jakarta, Kototabang, dan Maros dianalisis oleh Laboratorium Kimia BMKG Jakarta, sementara sampel dari Serpong dianalisis di Laboratorium PSIKLH, dan sampel dari Bandung dianalisis di Laboratorium LAPAN. Metode analisis air hujan yang dilakukan di laboratorium mengacu pada panduan EANET untuk pengujian deposisi basah (EANET, 2010).

Data yang digunakan dalam kajian ini adalah data pemantauan selama tahun 20152019 yang telah melewati jaminan mutu dan pengendalian mutu yang dikeluarkan oleh EANET, dan diverifikasi oleh $Q A / Q C$ manager. Masing-masing jumlah total data

Tabel 1. Informasi lokasi sampling di Indonesia

\begin{tabular}{|c|c|c|c|c|}
\hline Lokasi & Klasifikasi & Lintang & Bujur & Ketinggian (m) \\
\hline Serpong & pedesaan & $06^{0} 21^{\prime} 01,9$ " LS & $106^{0} 40^{\prime} 04,07^{\prime \prime} \mathrm{BT}$ & 64 \\
\hline Bandung & perkotaan & $06^{0} 53^{\prime} 41,63^{\prime \prime} \mathrm{LS}$ & $107^{0} 35^{\prime} 11,31^{\prime \prime} \mathrm{BT}$ & 753 \\
\hline Jakarta & perkotaan & $06^{0} 09^{\prime} 21,51$ ” LS & $106^{0} 50^{\prime} 32,67^{\prime \prime} \mathrm{BT}$ & 7 \\
\hline Kototabang & terpencil & $0^{0} 12^{\prime} 8.70 ”$ LS & $100^{0} 19^{\prime} 4.50{ }^{\prime \prime} \mathrm{BT}$ & 845 \\
\hline Maros & pedesaan & $04^{0} 59^{\prime} 50.29^{\prime} \mathrm{LS}$ & $119^{0} 34^{\prime} 17.73^{\prime \prime} \mathrm{BT}$ & 1 \\
\hline
\end{tabular}

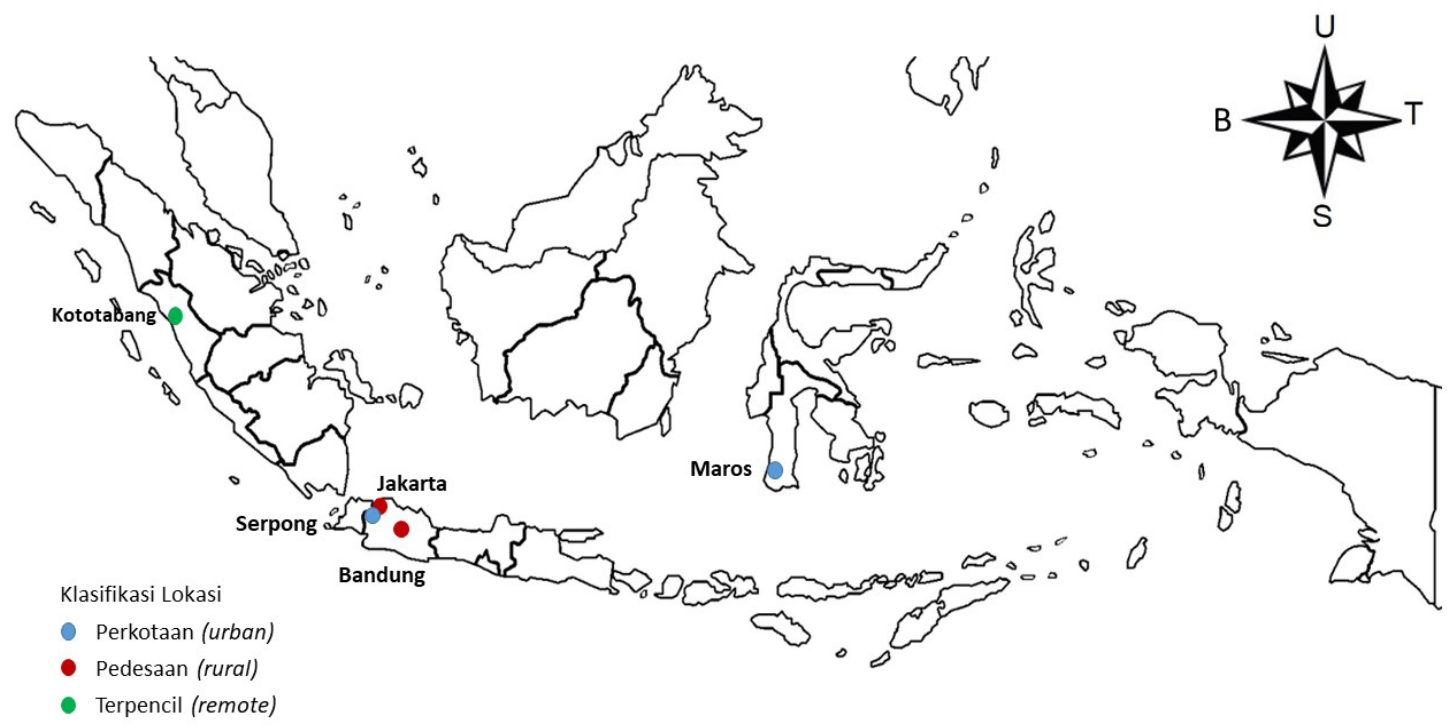

Gambar 1. Lokasi pemantauan deposisi asam di Indonesia 
Tabel 2. Metode analisis deposisi basah

\begin{tabular}{|c|c|c|c|}
\hline Lokasi & Parameter & Metode & Instrument \\
\hline \multirow[t]{4}{*}{ Serpong } & $\mathrm{pH}$ & Elektroda gelas & HORIBA F-22 \\
\hline & daya hantar listrik & Sel konduktivitas & HORIBA Navi DS-52 \\
\hline & $\mathrm{SO}_{4}^{2-}, \mathrm{NO}_{3}^{-}, \mathrm{Cl}^{-}$ & Kromatografi ion & DIONEX ICS5000 \\
\hline & $\begin{array}{l}\mathrm{Na}^{+}, \mathrm{NH}_{4}^{+}, \mathrm{K}^{+}, \mathrm{Mg}^{2+}, \\
\mathrm{Ca}^{2+}\end{array}$ & Kromatografi ion & DIONEX ICS5000 \\
\hline \multirow[t]{4}{*}{ Bandung } & $\mathrm{pH}$ & Elektroda gelas & HORIBA F-51 \\
\hline & $\mathrm{EC}$ & Sel konduktivitas & WTW Inolab Cond Level 2 \\
\hline & $\mathrm{SO}_{4}^{2-}, \mathrm{NO}_{3}^{-}, \mathrm{Cl}^{-}$ & Kromatografi ion & DIONEX ICS 1500 \\
\hline & $\begin{array}{l}\mathrm{Na}^{+}, \mathrm{NH}_{4}^{++}, \mathrm{K}^{+}, \mathrm{Mg}^{2+}, \\
\mathrm{Ca}^{2+}\end{array}$ & Kromatografi ion & DIONEX ICS 1600 \\
\hline Jakarta/ & $\mathrm{pH}$ & Elektroda gelas & THERMO Electron Corp. ORION 3 Star \\
\hline Kototabang/ & $\mathrm{EC}$ & Sel konduktivitas & THERMO Electron Corp. ORION 3 Star \\
\hline \multirow[t]{2}{*}{ Maros } & $\mathrm{SO}_{4}^{2-}, \mathrm{NO}_{3}^{-}, \mathrm{Cl}^{-}$ & Kromatografi ion & DIONEX ICS 1600 \\
\hline & $\begin{array}{l}\mathrm{Na}^{+}, \mathrm{NH}_{4}^{+}, \mathrm{K}^{+}, \mathrm{Mg}^{2+}, \\
\mathrm{Ca}^{2+}\end{array}$ & Kromatografi ion & DIONEX ICS 1600 \\
\hline
\end{tabular}

di Serpong $(n=395)$, Bandung $(n=461)$, Jakarta $(n=155)$, Kototabang $(n=195)$, dan Maros $(\mathrm{n}=135)$. Data diolah menggunakan Microsoft Excel dan Graphad Prism 5.0. Uji statistik non parametrik Kruskal-Wallis diaplikasikan untuk mengetahui perbedaan konsentrasi pencemar dominan yang sama di tiap lokasi.

\section{Hasil dan Pembahasan}

Melalui pemantauan secara berkala selama tahun 2015-2019 diperoleh data sebagai berikut:

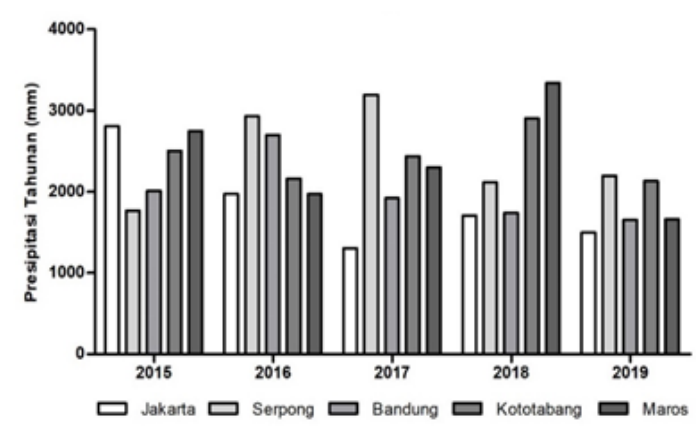

Sumber data: PSIKLH, BMKG, dan LAPAN

Gambar 1. Total presipitasi tahunan pada tahun 2015-2019

Kondisi topografi daerah yang meliputi wilayah pantai, lereng, pegunungan, maupun wilayah khusus dapat dihubungkan dengan banyaknya curah hujan di wilayah tersebut (Prasetyo, Irwand, \& Pusparini, 2018). Serpong, Jakarta, Bandung, dan Maros terletak di wilayah dengan curah hujan monsunal, sementara Kototabang mempunyai curah hujan ekuatorial (Aldrian \& Susanto, 2003).

Menurut pengamatan BMKG, dari data curah hujan rata-rata selama rentang waktu minimal 30 tahun, diperoleh normal curah hujan bulanan yang terbagi menjadi 3 kategori, yaitu rendah (0-100 $\mathrm{mm})$, menengah (100-300 $\mathrm{mm})$, tinggi $(300-500 \mathrm{~mm})$, dan sangat tinggi ( $>500$ $\mathrm{mm})$ (BMKG, 2017). Melalui Grafik 1 yang menggambarkan total dari presipitasi tahunan dari tiap-tiap kota yang dipantau, terlihat bahwa Jakarta memiliki total presipitasi paling kecil dibandingkan dengan lokasi lainnya. Tren ini ini berbeda dengan tren presipitasi sebelumnya pada tahun 2008-2015. Saat itu Serpong memiliki total presipitasi paling rendah dibandingkan dengan kota-kota lainya (Lestari, Nasution, Budiwati, Rachmawati, \& Indrawati, 2018).

Dalam kajian Charlson and Rodhe (1982) dinyatakan bahwa nilai $\mathrm{pH}$ air hujan dapat mengindikasikan potensi 
deposisi asam (Cui et al., 2020). Ratarata $\mathrm{pH}$ tertimbang berdasarkan weighted precipitation mean tahunan selama tahun 2015-2019 terlihat pada Tabel 3. Rata-rata nilai $\mathrm{pH}$ di lokasi pemantauan ini berada pada kisaran $\mathrm{pH}$ 4,6-6,4. Rata-rata $\mathrm{pH}$ di Jakarta adalah 4,84, Serpong 5,17, Bandung 5,55, Kototabang 5,23, dan Maros 5,28. Apabila dibandingkan dengan nilai ratarata tahunan $\mathrm{pH}$ presipitasi tertimbang selama tahun 2008-2015 pada tahun kajian sebelumnya di Serpong yaitu 4,86, Bandung 5,30, Jakarta 4,71, Maros 5,39, dan Kototabang 4,93 (Lestari et al., 2018), maka terlihat adanya kenaikan $\mathrm{pH}$ di seluruh lokasi pemantauan, kecuali Maros. Dari rata-rata nilai $\mathrm{pH}$ setiap tahun sepanjang 2015-2019, terlihat nilai $\mathrm{pH}<5,6$ yang mengindikasikan bahwa seluruh lokasi terkontaminasi senyawa asam kecuali di kota Bandung pada tahun 2018 dan 2019, yaitu masing- masing 5,66 dan 6,38. Hasil pemantauan ini tidak bertentangan dengan studi pemodelan kualitas udara menggunakan Weather and Research Forecasting (WRF)-Chem yang menunjukkan bahwa di kota Jakarta sebagai daerah perkotaan (urban) memiliki $\mathrm{pH}<5,6$ (Turyanti \& Chaerunnisa, 2017). Model tersebut mensimulasikan emisi, transportasi, pencampuran, dan transformasi polutan gasgas dan aerosol di atmosfer yang didukung oleh kondisi meteorologi (Turyanti \& Chaerunnisa, 2017).

Distribusi frekuensi $\mathrm{pH}>5,6$ di Bandung memiliki jumlah lebih tinggi dibanding kota lainnya, kemudian diikuti dengan distribusi $\mathrm{pH}$ di Serpong. Dua lokasi ini, Serpong $(n=395)$ dan Bandung $(n=461)$, memiliki jumlah sampel lebih banyak karena diambil setiap hari hujan apabila dibandingkan dengan lokasi-lokasi pemantauan milik BMKG yaitu Jakarta

Tabel 3. Rata-rata tahunan $\mathrm{pH}$ pada tahun 2015-2019

\begin{tabular}{lcccccc}
\hline Lokasi/Tahun & $\mathbf{2 0 1 5}$ & $\mathbf{2 0 1 6}$ & $\mathbf{2 0 1 7}$ & $\mathbf{2 0 1 8}$ & $\mathbf{2 0 1 9}$ & Rata-rata 2015-2019 \pm SD \\
\hline Serpong & 4,94 & 5,18 & 5,20 & 5,21 & 5,34 & $5,17 \pm 0,15$ \\
Jakarta & 4,84 & 4,95 & 4,89 & 4,69 & 4,86 & $4,85 \pm 0,10$ \\
Bandung & 5,36 & 5,08 & 5,25 & 5,66 & 6,38 & $5,55 \pm 0,51$ \\
Kototabang & 4,91 & 5,30 & 5,20 & 5,31 & 5,44 & $5,23 \pm 0,20$ \\
Maros & 5,24 & 5,24 & 5,31 & 5,38 & 5,23 & $5,28 \pm 0,06$ \\
\hline
\end{tabular}

Sumber data: PSIKLH, BMKG, dan LAPAN

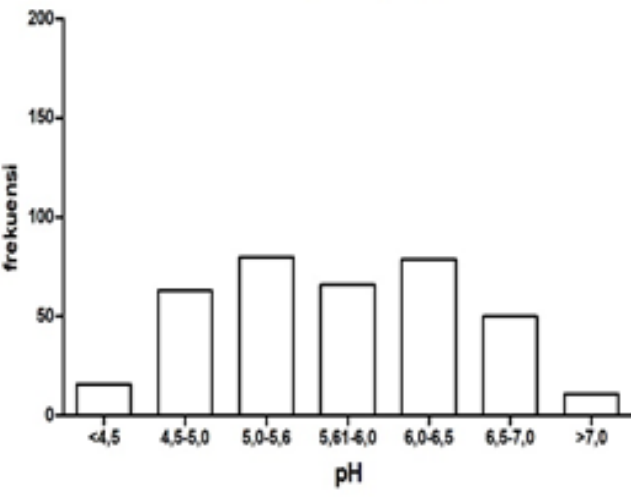

(a) Serpong

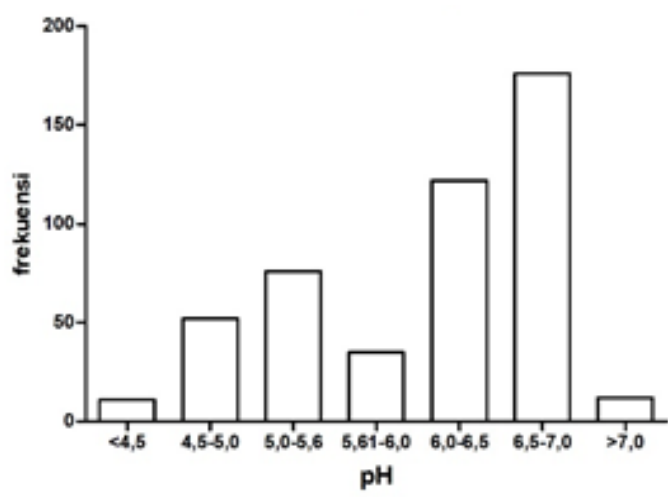

(b) Bandung

sumber data: PSIKLH \& LAPAN

Gambar 3. Distribusi pH di Serpong dan Bandung pada tahun 2015-2019 


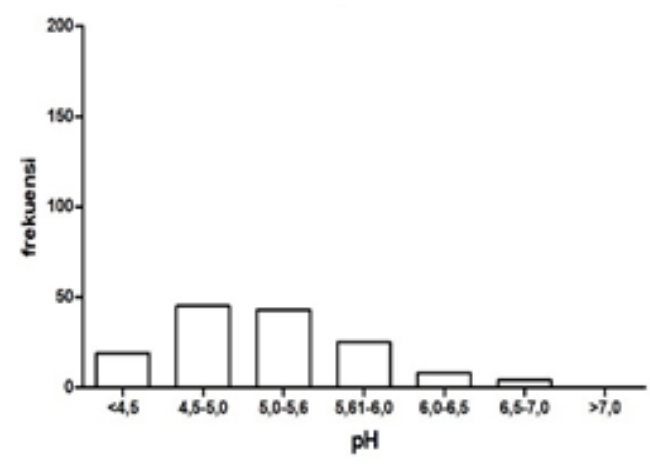

(a) Jakarta

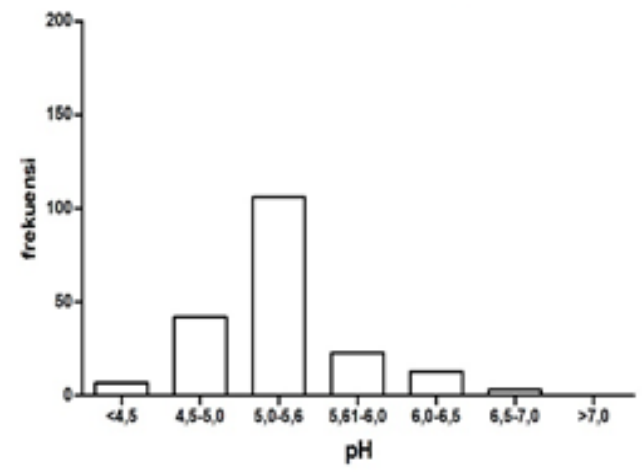

(b) Kototabang

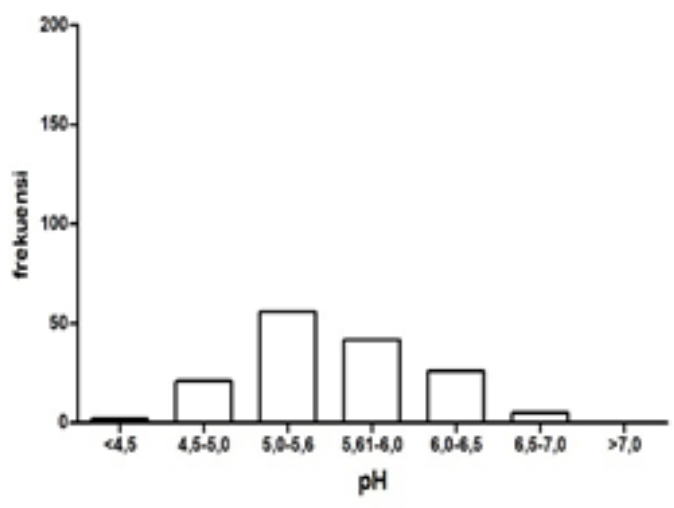

(c) Maros

Sumber data: BMKG Jakarta

Gambar 4. Distribusi pH di Jakarta, Kototabang dan Maros pada tahun 2015-2019

$(\mathrm{n}=155)$, Kototabang $(\mathrm{n}=195)$, dan Maros $(n=135)$ yang mempunyai sampel mingguan. Dominasi distribusi sampel tertinggi di Jakarta berada pada kisaran $\mathrm{pH}$ 4,5-4,9, sementara di Kototabang dan Maros pada kisaran $\mathrm{pH}$ 5,0-5,6.

Sifat asam air hujan yang dilihat dari nilai $\mathrm{pH}$ tergantung pada konsentrasi ion-ion yang terkandung di dalamnya seperti $\mathrm{SO}_{4}{ }^{2-}$ dan $\mathrm{NO}_{3}^{-}$, namun apabila pHnya lebih tinggi dari 6,0, maka hal tersebut diakibatkan oleh tingginya konsentrasi $\mathrm{NH}_{4}^{+}$sehingga terjadi netralisasi (EANET, 2016). Banyaknya asam yang jatuh ke permukaan bumi akan berpengaruh pada efek deposisi asam di lingkungan (Anil, Alagha, \& Karaca, 2017; EANET, 2016).

Rata-rata DHL di seluruh lokasi bervariasi dari $0,4-3,0 \mathrm{mS} \mathrm{m}$. Beberapa studi yang mengkaji hubungan korelasi matriks antara DHL dengan ion-ion dalam air hujan menunjukkan adanya korelasi positif antara tingginya nilai DHL dengan konsentrasi ion (Chon, Kim, Bae, \& Cho, 2015; Lara et al., 2001; Martins, Nogarotto, Mortatti, \& Pozza, 2019; Xiao, 2016). Gambar 6. menunjukkan rata-rata DHL yang terukur dalam air hujan, terlihat bahwa Kototabang memiliki nilai DHL paling rendah dibanding kota-kota lainnya.

Karakteristik senyawa kimia dalam air hujan berdasarkan data rata-rata tahunan di tiap lokasi dapat dilihat pada Gambar 6. Komponen kimia dari presipitasi di masing-masing lokasi akan membantu mengungkapkan informasi tingkat pencemaran, potensi sumber dan transportasi polutan (Anil et al., 2017; Chon et al., 2015). Di Serpong dan Jakarta, $\mathrm{NH}_{4}^{+}$dan $\mathrm{NO}_{3}^{-}$ merupakan ion kimia dominan, sementara 


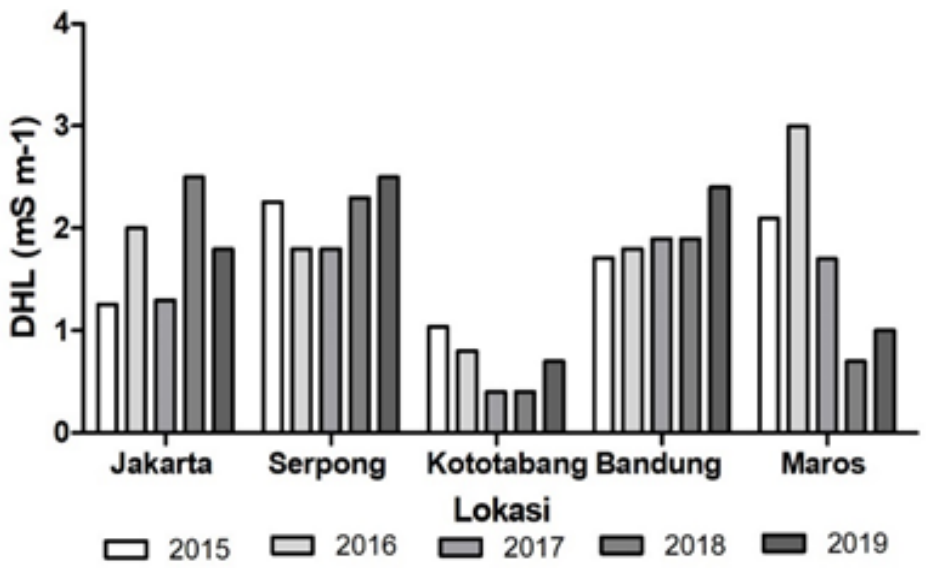

Sumber data: PSIKLH, BMKG, dan LAPAN

Gambar 5. Rata-rata tahunan daya hantar listrik (DHL) pada tahun 2015-2019

di Bandung adalah $\mathrm{NH}_{4}^{+}$dan nss $\mathrm{SO}_{4}^{2-}$. Ion $\mathrm{NO}_{3}^{-}$dan nss $\mathrm{SO}_{4}^{2-}$ di kota umumnya diakibatkan oleh kegiatan antropogenik seperti pembakaran bahan bakar fosil, sementara sumber $\mathrm{NH}_{4}^{+}$kemungkinan besar didominasi oleh sumber alamiah (Ceron et al., 2013; Likens, 2020; Yim, Gu, Shapiro, \& Stephens, 2019). Hasil uji statistik KruskallWallis tidak menunjukkan adanya perbedaan nyata secara statistik untuk parameter dominan yaitu $\mathrm{NH}_{4}^{+}$dan $\mathrm{SO}_{4}^{2-}$ di seluruh lokasi pemantauan $(\mathrm{p}<0.05)$.

Melalui kajian karakterisasi deposisi asam di Jakarta berdasarkan model Positive Matrix Factorization (PMF) menunjukkan $70,3 \% \mathrm{SO}_{4}^{2-}$ dan $71,6 \%$ nss- $\mathrm{SO}_{4}^{2-}$ berasal dari proses pembakaran bahan mengandung sulfur yang berasal dari emisi kendaraan diesel, sementara 90,6\% $\% \mathrm{NH}_{4}^{+}$dari sumber alami dan kegiatan pertanian, demikian pula dengan perhitungan PMF di Serpong yaitu $60,0 \% \mathrm{SO}_{4}^{2-}$ dan $61,8 \%$ nss- $\mathrm{SO}_{4}^{2-}$ berasal dari proses pembakaran, serta $60,5 \% \mathrm{NH}_{4}^{+}$ berasal dari sektor pertanian (Mukhtar et al., 2019). Karakteristik kimia di Kototabang dan Maros berbeda dengan lokasi lainnya. Ion dominan di Kototabang adalah nss $\mathrm{Ca}^{2+}$ dan $\mathrm{Cl}^{-}$, sementara di Maros adalah $\mathrm{Na}+$ dan $\mathrm{Cl}^{-}$. Karasterik wilayah pesisir pantai di Maros ini serupa dengan studi yang dilakukan di kota pesisir Wanli, Taiwan yang juga didominasi oleh $\mathrm{Na}+$ dan $\mathrm{Cl}^{-}$(Chen, Hsu, Huang, \& Zheng, 2020).

Pada Gambar 7. memperlihatkan komposisi ion-ion dalam air hujan di lokasilokasi pemantauan. Komposisi kimia air hujan di Kototabang memiliki konsentrasi paling rendah di antara kota lainnya. Hal ini sesuai dengan nilai DHL Kototabang yang juga paling rendah dibanding lokasi lainnya.

Secara ideal, komposisi anion dan kation seharusnya seimbang satu sama lainnya karena berhubungan dengan rumus kesetimbangan kimia (EANET, 2015a). Adapun adanya perbedaan konsentrasi total anion dan total kation biasanya disebabkan oleh adanya kontaminasi contoh serta beberapa parameter anion anorganik yang tidak dianalisis seperti $\mathrm{HCO}_{3}^{-}, \mathrm{F}^{-}, \mathrm{Br}$, $\mathrm{NO}_{2}^{-}$, dan $\mathrm{PO}_{4}^{3-}$ ataupun parameter anion organik seperti $\mathrm{HCOO}^{-}, \mathrm{CH}_{3} \mathrm{COO}^{-}$, dan $\left(\mathrm{COO}^{-}\right)_{2}$ (EANET, 2015a). Winkler (1986) menyatakan bahwa senyawa-senyawa karbonat $\left(\mathrm{CO}_{2(\mathrm{aq})}-\mathrm{H}_{2} \mathrm{CO}_{3}-\mathrm{HCO}_{3}{ }^{-}-\mathrm{CO}_{2}{ }^{3-}\right)$ harus diperhitungkan dalam keseimbangan ion, ketika $\mathrm{pH}$ mendekati netral atau lebih tinggi dari 6,0 (Pye et al., 2020). Analisis parameter kimia untuk seluruh ion-ion dalam deposisi basah ini dilakukan dengan instrumen ion kromatografi (IC) dengan mempertimbangkan jenis kolom yang dimiliki. IC memiliki kelebihan sensitivitas, 

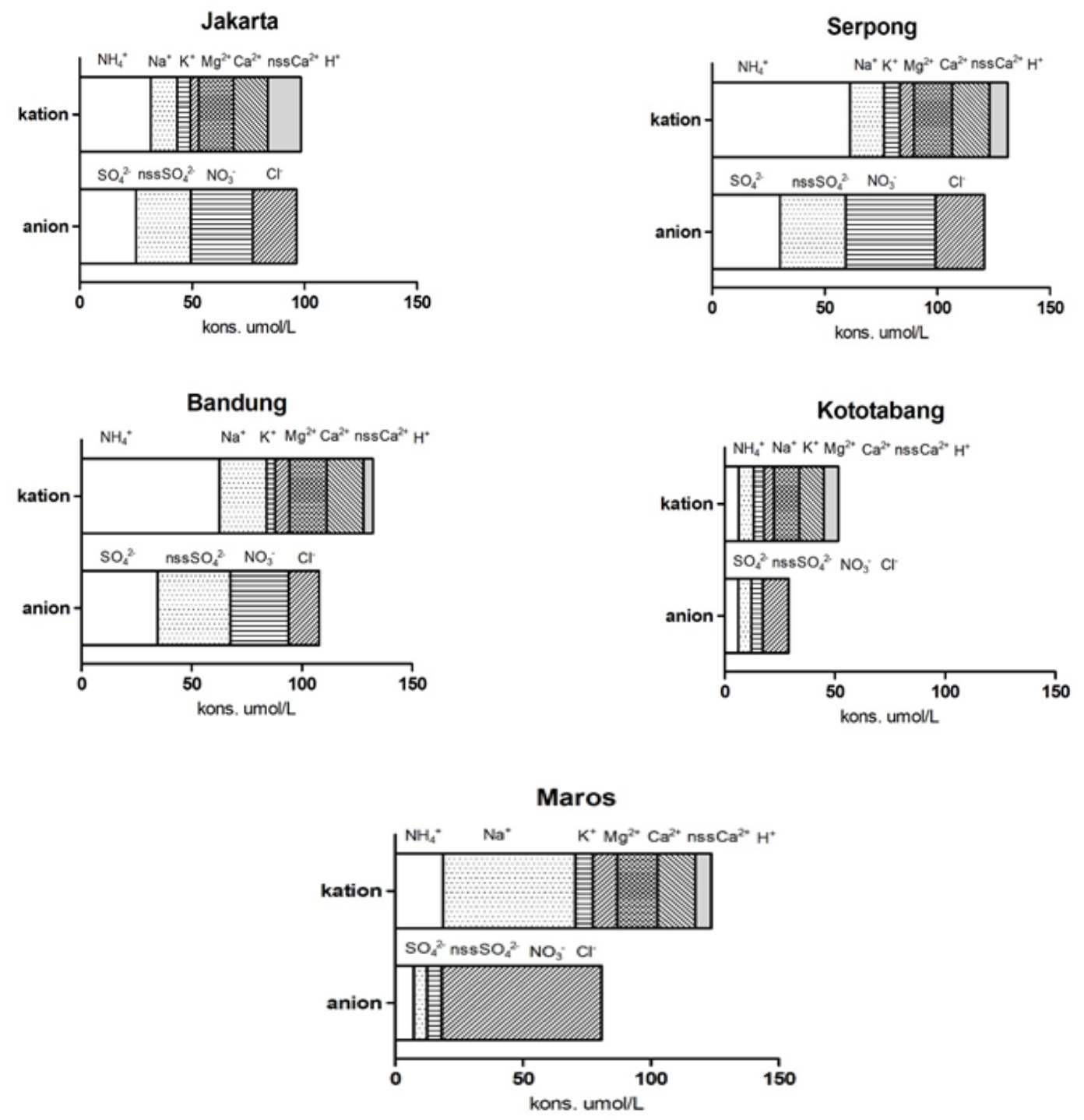

Gambar 6. Komposisi kimia dalam air hujan pada tahun 2015-2019

selektivitas, dengan waktu analisis yang relatif singkat (Dasgupta \& Maleki, 2019; Michalski, 2016; Nesterenko \& Paull, 2017).

Potensi penyebab keasaman air hujan dapat dilihat melalui ion $\mathrm{NO}_{3}^{-}$dan $\mathrm{nss}^{-2} \mathrm{SO}_{4}{ }^{2-}$ yang diidentifikasi melalui perhitungan fraksi nitrat untuk total $\mathrm{NO}_{3}^{-}$dan nss $\mathrm{SO}_{4}^{2-}$ dengan persamaan $\left[\mathrm{NO}_{3}^{-}\right] /\left(\left[\mathrm{NO}_{3}^{-}\right]+[\mathrm{nss}\right.$ $\left.\mathrm{SO}_{4}^{2-}\right]$ ), sementara dalam proses netralisasi dihitung melalui fraksi amonium dengan persamaan $\left[\mathrm{NH}_{4}^{+}\right] /\left(\left[\begin{array}{ll}\mathrm{NH}_{4}^{+}\end{array}\right]+\left[\begin{array}{lll}\mathrm{nss} & \mathrm{Ca}^{2+}\end{array}\right]\right.$ (Balasubramanian, Victor, \& Chun, 2001; Chate \& Devara, 2009; EANET, 2016; Szép et al., 2018; Thepanondh, 2004).
Seperti terlihat pada Tabel 4. fraksi ekuivalen nitrat pada tahun 2015-2019 di Jakarta, Serpong, dan Bandung memiliki nilai $>0,5$. Nilai tersebut menunjukkan bahwa $\mathrm{HNO}_{3}$ lebih berpengaruh dalam terjadinya deposisi asam, tetapi di Kototabang dan Maros lebih disebabkan oleh $\mathrm{H}_{2} \mathrm{SO}_{4}$. Hal ini juga didukung dengan rata-rata deposisi perbandingan nss $\mathrm{SO}_{4}^{2-}$ dan $\mathrm{NO}_{3}^{-}(\mathrm{mmol} /$ $\mathrm{m}^{2} /$ tahun) pada tahun 2015-2019 (Gambar 7.) menunjukkan bahwa konsentrasi $\mathrm{NO}_{3}^{-}$ lebih tinggi dibanding dengan nss $\mathrm{SO}_{4}^{2-}$. dan mengindikasikan kesesuaian potensi keasaman air hujan dari ion-ion tersebut 
Tabel 4. Fraksi ekuivalen nitrat dan amonium

\begin{tabular}{lcc}
\hline Lokasi & Fraksi ekuivalen nitrat & Fraksi ekuivalen amonium \\
\hline Serpong & 0,567 & 0,788 \\
Jakarta & 0,509 & 0,675 \\
Bandung & 0,548 & 0,790 \\
Kototabang & 0,444 & 0,362 \\
Maros & 0,485 & 0,558 \\
\hline
\end{tabular}

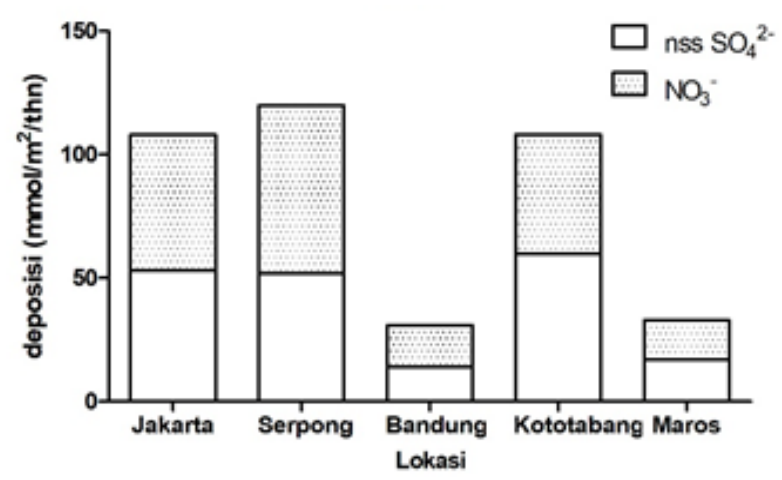

Gambar 7. Rata-rata perbandingan deposisi nss $\mathrm{SO}_{4}{ }^{2-}$ dan $\mathrm{NO}_{3}^{-}$pada tahun 2015-2019

dengan nilai $\mathrm{pH}$ yang diperoleh selama pemantauan.

Di sisi lain, fraksi ekuivalen amonium (nilai<0,5) di Kototabang menunjukkan bahwa peran $\mathrm{CaCO}_{3}$ lebih dominan dalam menetralisasikan senyawa asam, sementara di kota-kota lainnya lebih didominasi oleh NH3. Hal ini masih memiliki pola serupa dengan perhitungan fraksi ekuivalen nitrat dan amonium di tahun sebelumnya.

Hasil perhitungan komposisi kimia dalam deposisi basah ini menunjukkan hasil yang serupa dalam deposisi kering di lokasi Jakarta, Bandung, dan Serpong, yang menyatakan bahwa $\mathrm{NH}_{3}$ merupakan bagian terbesar dari komponen fase gas (Aikawa, Hiraki, Mukai, \& Murano, 2008) . Kawasan Asia Timur yang memiliki data emisi $\mathrm{NH}_{3}$ dan $\mathrm{NH}_{4}^{+}$dalam air hujan yang cukup tinggi (Chao, Zi-Fa, \& Gbaguidi, 2010; EANET, 2015a) tidak bertentangan dengan hasil pemantauan dalam penelitian ini. Pemantauan sebelumnya di tahun 20082015 pun memberikan pola karakteristik yang serupa (Lestari et al., 2018). Rasio
$\mathrm{NH}_{4}^{+}$di daratan kontinental umumnya lebih tinggi dibanding daerah pesisir dan pulau, sehingga $\mathrm{NH}_{4}^{+}$merupakan senyawa penting dalam presipitasi kimia di wilayah benua Asia Timur (Chao et al., 2010). $\mathrm{NH}_{3}$ atmosferik memegang peranan penting dalam proses terjadinya hujan asam, deposisi nitrogen, dan polusi akibat partikel halus (Liu et al., 2019). $\mathrm{NH}_{3}$ juga sebagian besar berpartisi menjadi butiran awan untuk nilai $\mathrm{pH}<6$, tetapi fraksi yang cukup besar dapat tetap berada dalam fase gas untuk nilai pH $>6$ (Pye et al., 2020). Berdasarkan kajian The Model Inter-Comparison Study for Asia (MICS-Asia) phase III, $\mathrm{NH}_{4}^{+}$aerosol dan $\mathrm{NH}_{3}$ merupakan ekivalen dari $\mathrm{SO}_{4}^{2-}$ dan $\mathrm{NO}_{3}^{-}$, sifat deposisi aerosol $\mathrm{NH}_{4}^{+}$dan $\mathrm{NH}_{3}$ menunjukkan perpaduan kriteria deposisi sulfur (S) dan deposisi nitrogen (N) (Itahashi et al., 2020).

Adanya perbedaan pola komposisi kimia di setiap lokasi disebabkan oleh sumber pencemar yang berbeda. Kegiatan antropogenik yang terdapat pada setiap klasifikasi lokasi akan memberikan potensi 
sumber emisi yang berbeda di sekitar lokasi sampling (Monteith et al., 2016). Sebuah studi di China menunjukkan bahwa area terdampak deposisi asam yang parah di wilayah selatan telah berkurang melalui pengendalian polutan emisi, tetapi area terdampak deposisi asam dalam kategori sedang telah meluas di wilayah utara, terkait dengan tingginya perkembangan industri dan transportasi (Yu et al., 2017).

Di negara dengan empat musim, variasi komposisi kimia dapat berbedabeda seiring adanya perbedaan pola musim, kondisi meteorologi, kondisi permukaan, dan jenis spesies kimia (EANET, 2015b) serta adanya kontribusi campuran sumber lokal dan regional (Ceron et al., 2013). Konsentrasi senyawa nitrat umumnya tinggi di musim dingin dan relatif rendah di musim panas, sementara untuk parameter amonium maupun sulfat tidak ada perbedaan (Aikawa et al., 2008). Kontribusi pencemar lintas batas yang lebih tinggi dari Asia terjadi pada musim semi di Jepang dan musim dingin di Korea Selatan, dan kondisi ini diprediksi akan mengalami penurunan seiring perubahan cuaca dan iklim (Yim et al., 2019). Beberapa kajian di wilayah Asia Timur menekankan pentingnya data $\mathrm{PM}_{2,5}$ dalam kaitannya dengan pencemar lintas batas yang berkontribusi pada deposisi asam, namun di Indonesia, data tersebut hanya tersedia di kota Jakarta pada tahun 2017-2019.

Pada skala internasional, kajian mengenai deposisi asam yang berlangsung di negara-negara Eropa dan Amerika Utara sejak tahun 1970 menunjukkan bahwa melalui pengendalian pencemaran udara, di wilayah-wilayah tersebut, termasuk Jepang dan Australia, telah mengalami peningkatan kualitas udara (Grennfelt et al., 2020). Hal tersebut ditandai dengan terjadinya penurunan emisi SO2, NOx, senyawa organik volatil (VOCs), dan senyawa polutan lainnya (Maas et al., 2016), meskipun di beberapa negara, masalah pencemaran udara masih menjadi isu lingkungan prioritas (Grennfelt et al., 2020).

\section{Simpulan}

Berdasarkan analisis data dapat disimpulkan bahwa ion $\mathrm{NH}_{4}^{+}$dan $\mathrm{SO}_{4}^{2-}$ merupakan senyawa pencemar dominan yang terdapat dalam deposisi basah. Dalam pemantauan selama tahun 2015-2019 menunjukkan tidak adanya perbedaan nyata secara statistik untuk parameter $\mathrm{NH}_{4}^{+}$ dan $\mathrm{SO}_{4}{ }^{2-}$ di tiap lokasi. Meskipun $\mathrm{pH}$ di seluruh lokasi $<5,6$, namun hasil evaluasi selama 5 tahun ini menunjukkan adanya kenaikan nilai $\mathrm{pH}$ air hujan di seluruh lokasi pemantauan dibandingkan dengan tahuntahun sebelumnya. Melalui perhitungan fraksi ekuivalen nitrat, diketahui bahwa $\mathrm{NO}_{3}^{-}$ lebih berpengaruh dalam terjadinya deposisi asam di Jakarta, Serpong, dan Bandung, namun di Kototabang dan Maros lebih disebabkan oleh $\mathrm{H}_{2} \mathrm{SO}_{4}$. Fraksi ekuivalen amonium di Kototabang menunjukkan peran $\mathrm{CaCO}_{3}$ yang lebih dominan dalam proses netralisasi senyawa asam, sementara di kotakota lainnya lebih didominasi oleh $\mathrm{NH}_{3}$.

\section{Ucapan Terima Kasih}

Penulis mengucapkan terima kasih kepada semua pihak yang terlibat dalam kegiatan ini, yaitu PSIKLH-KLHK, LAPANBRIN, dan BMKG yang menyediakan fasilitas, sumber daya, dan dana pemantauan, serta seluruh tim yang melakukan sampling dan analisis di masing-masing laboratorium.

\section{Kepengarangan}

Seluruh penulis merupakan suatu kesatuan tim tak terpisahkan yang memberikankontribusi dalam tiap bagiannya. Penulis pertama melakukan penyusunan tulisan dan verifikasi data, sementara penulis lainnya melakukan pengujian, pengolahan, dan membantu interpretasi data di masingmasing institusi. 


\section{Daftar Pustaka}

Aikawa, M., Hiraki, T., Mukai, H., \& Murano, K. (2008). Characteristic variation of concentration and chemical form in sulfur, nitrate, ammonium, and chloride species observed at urban and rural sites of Japan. Water, Air, Soil Pollut., 190(1), 287-297. doi:10.1007/s11270-007-9600-0

Aldrian, E., \& Susanto, D. (2003). Identification of three dominant rainfall regions within Indonesia and their relationship to sea surface temperature. Int $J$ of Climatol., 23(12), 1435-1452.

Anil, I., Alagha, O., \& Karaca, F. (2017). Effects of transport patterns on chemical composition of sequential rain samples: trajectory clustering and principal component analysis approach. Air Quality, Atmosphere \& Health, 10(10), 1193-1206.

APIS. (2016). Sulphur dioxide : emission and trends. Retrieved from http://www.apis. ac.uk/overview/pollutants/overview_SO2. htm

Balasubramanian, R., Victor, T., \& Chun, N. (2001). Chemical and statistical analysis of precipitation in Singapore. Water, Air, and Soil Pollution, 130(1), 451-456.

BMKG. (2017). Normal hujan bulanan. Retrieved from https://bmkgsampali.net/ normal-hujan-bulanan/

Burns, D. A., Aherne, J., Gay, D. A., \& Lehmann, C. M. (2016). Acid rain and its environmental effects: Recent scientific advances. Atmospheric Environment, 146, $1-4$.

Ceron, R. M., Ceron, J. G., Carballo, C. G., Aguilar, C. A., Montalvo, C., Benitez, J. A., . . Gomez, M. M. (2013). Chemical composition, fluxes and seasonal variation of acid deposition in Carmen Island, Campeche, Mexico. J. Environ. Prot., 5056. doi:10.4236/jep.2013.48A1007

Chao, G., Zi-Fa, W., \& Gbaguidi, E. A. (2010). Ammonium variational trends and the ammonia neutralization effect on acid rain over East Asia. Atmospheric and Oceanic Science Letters, 3(2), 120-126.

Chate, D., \& Devara, P. (2009). Acidity of raindrop by uptake of gases and aerosol pollutants. Atmospheric Environment, 43(8), 1571-1577.

Chen, H.-Y., Hsu, L.-F., Huang, S.-Z., \& Zheng, L. (2020). Assessment of the Components and Sources of Acid Deposition in Northeast Asia: A Case Study of the Coastal and Metropolitan Cities in Northern Taiwan. Atmosphere, 11(9), 983.

Chon, K., Kim, Y., Bae, D., \& Cho, J. (2015). Confirming anthropogenic influences on the major organic and inorganic constituents of rainwater in an urban area. Drinking Water Engineering and Science, 8(2), 35-48.

Cui, L., Liang, J., Fu, H., \& Zhang, L. (2020). The contributions of socioeconomic and natural factors to the acid deposition over China. Chemosphere, 253, 126491.

Dasgupta, P.K., \& Maleki, F. (2019). Ion exchange membranes in ion chromatography and related applications. Talanta, 204, 89-137.

Duan, L., Yu, Q., Zhang, Q., Wang, Z., Pan, Y., Larssen, T., . . . Mulder, J. (2016). Acid deposition in Asia: emissions, deposition, and ecosystem effects. Atmospheric Environment, 146, 55-69. doi:https://doi. org/10.1016/j.atmosenv.2016.07.018

EANET. (2010). Technical manual on wet deposition. Niigata: EANET.

EANET. (2015a). Data Report of Acid Deposition in East Asia 2014. Retrieved from Niigata:

EANET. (2015b). Strategy paper on future direction of monitoring for dry deposition of the EANET (2016-2020). Retrieved from Niigata:

EANET. (2016). Third periodic report on the state of acid deposition in East Asia Part II- National assesment. Niigata: EANET.

Grennfelt, P., Engleryd, A., Forsius, M., Hov, Ø., Rodhe, H., \& Cowling, E. (2020). Acid rain and air pollution: 50 years of progress in environmental science and policy. Ambio, 49(4), 849-864.

Itahashi, S., Ge, B., Sato, K., Fu, J. S., Wang, X., Yamaji, K., . . . Liao, H. (2020). MICS-Asia III: overview of model intercomparison and evaluation of acid deposition over Asia. Atmospheric Chemistry and Physics, 20(5), 2667-2693.

Lara, L., Artaxo, P., Martinelli, L., Victoria, R., Camargo, P., Krusche, A., . . . Ballester, 
M. (2001). Chemical composition of rainwater and anthropogenic influences in the Piracicaba River Basin, Southeast Brazil. Atmospheric Environment, 35(29), 4937-4945.

Lestari, R. P., Nasution, R. I., Budiwati, T., Rachmawati, E., \& Indrawati, A. (2018). Status deposisi basah di beberapa wilayah pemantauan di Indonesia periode 20082015. Ecolab, 12(2), 71-82.

Likens, G. E. (2020). Atmospheric acid deposition. Atmosphere and Climate, 45.

Liu, M., Huang, X., Song, Y., Tang, J., Cao, J., Zhang, X., ... Zhu, T. (2019). Ammonia emission control in China would mitigate haze pollution and nitrogen deposition, but worsen acid rain. Proceedings of the National Academy of Sciences, 116(16), 7760. doi:10.1073/pnas.1814880116.

Maas, R., Grennfelt, P., Amann, M., Harnett, B., Kerr, J., Berton, E., . . . Reis, S. (2016). Towards Cleaner Air. Scientific Assessment Report 2016.

Martins, E. H., Nogarotto, D. C., Mortatti, J., \& Pozza, S. A. (2019). Chemical composition of rainwater in an urban area of the southeast of Brazil. Atmospheric Pollution Research, 10(2), 520-530.

Michalski, R. (2016). Application of IC-MS and $I C-I C P-M S$ in environmental research: Wiley Online Library.

Monteith, D., Henrys, P., Banin, L., Smith, R., Morecroft, M., Scott, T., . . . Bowmaker, V. (2016). Trends and variability in weather and atmospheric deposition at UK Environmental Change Network sites (1993-2012). Ecological indicators, 68, 21-35.

Mukhtar, R., Lestari, R., Hindratmo, B., Nelson, R., Nugraha, M., \& Suharguniyawan. (2019). Characterizing acid deposition's pollutant sources in Serpong and Jakarta using positive matrix factorization model. Paper presented at the INAFOR, Bogor.

Nesterenko, P. N., \& Paull, B. (2017). Ion chromatography Liquid Chromatography (pp. 205-244): Elsevier.
Prasetyo, B., Irwand, H., \& Pusparini, N. (2018). Karakteristik curah hujan berdasarkan ragam topografi di Sumatera Utara. Jurnal Sains \& Teknologi Modifikasi Cuaca, 19(1), 11-20.

Pye, H. O., Nenes, A., Alexander, B., Ault, A. P., Barth, M. C., Clegg, S. L., .. . Herrmann, H. (2020). The acidity of atmospheric particles and clouds. Atmospheric Chemistry and Physics, 20(8), 4809-4888.

Sase, H. (2017). Acid deposition air pollution impacts on plants in East Asia (pp. 43-53): Springer.

Szép, R., Mateescu, E., Niță, I.-A., Birsan, M.-V., Bodor, Z., \& Keresztesi, Á. (2018). Effects of the Eastern Carpathians on atmospheric circulations and precipitation chemistry from 2006 to 2016 at four monitoring stations (Eastern Carpathians, Romania). Atmospheric Research, 214, 311-328.

Thepanondh, S. (2004). A study of wet and dry deposition processes for regional air pollution and atmospheric deposition modeling. (Ph.D), Monash University, Melbourne.

Turyanti, A., \& Chaerunnisa, C. (2017). The estimation of rainwater acidity level based on the ambient air pollutants concentration (Case Study: DKI Jakarta). Agromet, 31(2), 71-79.

Xiao, J. (2016). Chemical composition and source identification of rainwater constituents at an urban site in Xi' an. Environmental earth sciences, 75(3), 209.

Yim, S. H. L., Gu, Y., Shapiro, M. A., \& Stephens, B. (2019). Air quality and acid deposition impacts of local emissions and transboundary air pollution in Japan and South Korea. Atmospheric Chemistry and Physics, 19(20), 13309-13323.

Yu, H., He, N., Wang, Q., Zhu, J., Gao, Y., Zhang, Y., . . . Yu, G. (2017). Development of atmospheric acid deposition in China from the 1990s to the 2010s. Environ. Pollut., 231, 182-190. 